\title{
Protein beverages containing anthocyanins of jabuticaba
}

\author{
Juliana de Cássia Gomes ROCHA ${ }^{1 \star}$, Kéllen Wanessa Coutinho VIANA ${ }^{1}$, Adriana Corrêa MENDONÇA ${ }^{1}$, \\ Nathália de Andrade NEVES ${ }^{1}$, Antônio Fernandes de CARVALHO ${ }^{1}$, Valéria Paula Rodrigues MINIM ${ }^{1}$, \\ Frederico Augusto Ribeiro de BARROS ${ }^{1}$, Paulo César STRINGHETA ${ }^{1}$
}

\begin{abstract}
The objective of this study was to develop, characterize and evaluate the stability of whey protein beverages containing anthocyanins from jabuticaba skins. Beverage formulations containing 0.5\% (F1), 2.0\% (F2), 4.0\% (F3) and 6.0\% (F4) of whey proteins and $2.0 \mathrm{~mL}$ of the concentrated phenolic extract from jabuticaba skins were developed. Physicochemical parameters ( $\mathrm{pH}$, acidity, total soluble solids, protein content, viscosity, color), antioxidant capacity, total anthocyanins and total phenols of the beverages were determined. In addition, a sensory acceptance test and a stability study were performed. The physicochemical analyses indicated that the protein concentration significantly $(\mathrm{p}<0.05)$ affected the values of acidity, total soluble solids, total phenols and antioxidant capacity. The protein content also influenced the total color difference $(\Delta \mathrm{E})$ between formulations. The greater differences were observed in the formulation pairs containing low and high protein contents. The formulations F1, F2 and F3 were equally accepted on overall impression and color attributes. The stability study demonstrated that there was no significant change ( $p>0.05$ ) in the total anthocyanins and in the physicochemical properties of $F 3$ over storage time, which indicated a good stability and a great market potential of the whey protein beverages containing anthocyanins from jabuticaba skins.
\end{abstract}

Keywords: whey proteins; phenolic compounds; antioxidants; skins of jabuticaba; Plinia cauliflora.

Practical Application: Protein beverage with high protein content of anthocyanins from jabuticaba Skins.

\section{Introduction}

Over the recent years, there was a great interest of the population in consuming natural foods, due to their alleged beneficial health effects. This fact is related to the non-nutritional constituents, with bioactive properties, which typically occur in small quantities in these foods (Quideau et al., 2011). There are many studies performed in order to characterize, identify and extract these compounds, as well as to evaluate their effects on human health through in vitro and in vivo assays. However, there are only few studies related to the application of these compounds in food matrices of daily consumption, so that they can really get to the table of consumers and contribute to improve quality of life of the population.

The jabuticaba skin is an important source of phenolic compounds, especially anthocyanins. Although the skins are not directly consumed, they can be used in the production of extracts and jellies. Thus, the phenolic extracts from jabuticaba skins are very interesting for industrial purposes, due to their potential use as natural colorants and their antioxidant capacity (Silva et al., 2014; Rodrigues et al., 2015).

There are numerous reports in the literature describing the use of cheese whey in beverages with the purpose to avoid its waste and take advantage of its high protein quality. In the early 1990s, the cheese whey was considered a dairy industry by-product due to the large volume produced (Neves, 1993; Sabaa-srur et al.,
1995; Siso, 1996). Nowadays, it is considered a co-product, due to the beneficial properties of its constituents. The whey proteins have become popular because of their high nutritional value and high content of essential amino acids of branched chain. These specific amino acids stimulate intracellular pathways associated with the muscle protein synthesis (Katsanos et al., 2006; Pescuma et al., 2010). The characteristics of these proteins have led to an increase of their use as food ingredient and stimulated more research on the development of new techniques for their concentration, separation and fractionation.

The potential presented by the whey proteins and jabuticaba anthocyanins motivate the development of new food products. Thus, the objective of this work was to develop, characterize and evaluate the stability of beverages, combining the high nutritional quality of whey proteins with the antioxidant capacity of anthocyanins from jabuticaba skins.

\section{Materials and methods}

\subsection{Raw material}

Jabuticaba (Plinia cauliflora) fruits were collected in an experimental field from the Federal University of Vicosa, Minas Gerais, Brazil. The commercial whey protein concentrate (WPC60) was provided by the company Gemacom Tech. The cheese whey 
was obtained during the manufacture of mozzarella cheese, in a dairy industry from Viçosa, Minas Gerais, Brazil.

\subsection{Microfiltration and ultrafiltration of cheese whey}

The whey was subjected to centrifugation and then to the membrane filtration operation: microfiltration and ultrafiltration. The whey microfiltration was held in a Tetra Pak@ processing equipment, France. The whey was heated at $50^{\circ} \mathrm{C}$ and tangentially filtered through a tubular ceramic membrane ("Membralox ${ }^{\circledR ”) ~ w i t h ~}$ pore sizes of $0.8 \mu \mathrm{m}$, permeation speed of $7.2 \mathrm{~m} \cdot \mathrm{s}^{-1}$, a system with total membrane area of $0.24 \mathrm{~m}^{2}$ and a transmembrane pressure of 0.5 bar, thereby obtaining the whey permeate (WP). The whey ultrafiltration was performed in a pilot plant ("WGM systems"), using an open system. The whey was filtered through a spiral type polysulfone membrane ("Koch Membranes") with a molar mass cutoff of $10 \mathrm{kDa}$, filtering area of $3.0 \mathrm{~m}^{2}$, operation temperature of $35{ }^{\circ} \mathrm{C}$ and operational pressure between 2.1 and 8.3 bars, obtaining the whey retentate (WR).

\subsection{Phenolic extraction from jabuticaba skins}

Approximately $40 \mathrm{~g}$ of jabuticaba skins were ground in a mixer (Dellar, Gourmet DMX433 model, China) and then mixed with $70 \%$ acidified ethanol $(\mathrm{v} / \mathrm{v})(\mathrm{pH}=2)$ containing citric acid. The extraction was performed for 24 hours under refrigeration $\left(5 \pm 2{ }^{\circ} \mathrm{C}\right)$. The phenolic extract was filtered under vacuum using a Whatman $n^{\circ} 1$ filter paper and concentrated in a vacuum rotary evaporator (IKA RV 10, LabScience), at a temperature of $40^{\circ} \mathrm{C}$. The phenolic extracts were stored under refrigeration $\left(5 \pm 2{ }^{\circ} \mathrm{C}\right)$ until further analysis.

\subsection{Determination of the total anthocyanins and phenolic content in the extract}

The content of total anthocyanins was determined according to the method described by Lees \& Francis (1972) and the results were expressed as $\mathrm{mg}$ of anthocyanins $\cdot \mathrm{mL}^{-1}$ of extract. Total phenols content was determined according to Singleton \& Rossi (1965), using the Folin-Ciocalteu reagent and gallic acid as standard. The results were expressed as $\mathrm{mg}$ of gallic acid equivalent $\left(\mathrm{GAE} \cdot \mathrm{mL}^{-1}\right)$ of extract.

\subsection{Identification and quantification of anthocyanins in the extract}

The analysis was performed on an Agilent 1100 Series system (Agilent, Germany) equipped with a diode array detector (G1315B) and LC/MSD Trap VL (G2445C VL) electrospray ionization mass spectrometry (ESI-MS ${ }^{n}$ system, coupled to an Agilent ChemStation (version B.01.03) data-processing. The mass spectra data were processed with the Agilent LC/MS Trap software (version 5.3). The anthocyanins were analyzed following a method described by Rebello et al. (2013). The phenolic extract was injected, after dilution in $\mathrm{HCl} 0,1 \mathrm{~N} \mathrm{1:5}$, in a reversed-phase column Zorbax Eclipse XDB-C18 (2.1 × $150 \mathrm{~mm}$; $3.5 \mu \mathrm{m}$ particle; Agilent, Germany) kept at $40^{\circ} \mathrm{C}$. The flow rate was $0.19 \mathrm{~mL} / \mathrm{min}$. Mobile phase A was acetonitrile/water/formic acid (3:88.5:8.5, v/v/v) and mobile phase B was acetonitrile/water/formic acid (50:41.5:8.5, v/v/v). The gradient elution was: $0 \mathrm{~min}(97 \% \mathrm{~A}$ and $3 \% \mathrm{~B}), 20 \mathrm{~min}(72 \% \mathrm{~A}$ and $28 \% \mathrm{~B})$, $34 \mathrm{~min}(57 \% \mathrm{~A}$ and $43 \% \mathrm{~B}), 36 \mathrm{~min}(100 \% \mathrm{~B}), 42 \min (100 \% \mathrm{~B})$ and $45 \mathrm{~min}(97 \% \mathrm{~A}$ and $3 \% \mathrm{~B})$. For the anthocyanins identification, ESI/MS-MS was used in the positive ionization mode following the parameters: dry gas $\mathrm{N}_{2}$ with flow of $8 \mathrm{~L} \cdot \mathrm{min}^{-1}$, temperature of $325^{\circ} \mathrm{C}$ and nebulization with $\mathrm{N}_{2}$ at 50 psi. The ionization and fragmentation were optimized by the direct insertion of malvidin-3,5-diglucoside standard solutions in the positive ionization mode. The identification was based on spectroscopic data (UV-Vis and MS/Ms). The quantification of the anthocyanins was done based on the chromatographic data obtained at $520 \mathrm{~nm}$ using standard calibration curves.

\subsection{Beverage formulations}

Beverage formulations $(\mathrm{F})$ were elaborated using four different concentrations of whey proteins (F1: 0.5\%; F2: 2.0\%; F3: $4.0 \%$ and F4: $6.0 \%)$. The whey permeate (WP) and whey retentate (WR) were used in F1 and F2 formulations, respectively. The commercial whey protein concentrate (WPC 60) was used in the beverages containing higher levels of proteins (F3 and F4). The remaining ingredients and additives were mineral water, sugar (15\% w/v), strawberry pulp $(10 \% \mathrm{w} / \mathrm{v})$, gum arabic $(0.45 \% \mathrm{w} / \mathrm{v})$, potassium sorbate $(0.03 \% \mathrm{w} / \mathrm{v})$, acidulant (citric acid) and strawberry flavor (Duas Rodas Industrial). The $\mathrm{pH}$ of the beverages was standardized by acidifying with citric acid to $\mathrm{pH}$ 4.0. These beverage formulations were subjected to a heat treatment $\left(63^{\circ} \mathrm{C}\right.$ for 30 minutes $)$ and then, $2.0 \mathrm{~mL}$ of the jabuticaba skin phenolic extract was added in each formulation, in order to obtain beverages containing about $2.0 \mathrm{mg}$ of anthocyanins $\cdot 100 \mathrm{~g}^{-1}$ of beverage. The beverages were produced in three repetitions and stored at refrigeration temperature $\left(5 \pm 2{ }^{\circ} \mathrm{C}\right)$, until further analysis.

\subsection{Physical-chemical composition}

It was used a digital pHmeter (Digimed DM 20) for determination of the $\mathrm{pH}$. The soluble solids content ( $\left.{ }^{\circ} \mathrm{Brix}\right)$, obtained by the direct reading of a Leica refractometer (Leica AR 200 model, New York, USA), and the titratable acidity ( $\mathrm{g}$ of citric acid $\cdot 100^{-1} \mathrm{~g}$ ) were determined according to Instituto Adolfo Lutz (2008). The protein concentration was determined according to the Kjeldahl method (conversion factor of 6.38) (Association of Official Analytical Chemists, 2005). The rheological measurements of the beverages were performed in a rheometer having concentric cylinders (Searle type, Brookfield Engineering Laboratories, R/S plus SST 2000, Inc., EUA), equipped with Rheo 2000 software, at a temperature of $10^{\circ} \mathrm{C}$. The DG DIN cylindrical sensor was used as a measuring system, for 2 minutes, completing a total of 30 points.

\subsection{Color determination}

The colorimetric measurements were performed by direct reading of the reflectance of the coordinate system $\mathrm{L}^{*}, \mathrm{a}^{*}$ and $\mathrm{b}^{\star}$, applying the CIELAB color scale with D65 illuminant and a $10^{\circ}$ observation angle, using a Hunter Lab colorimeter (ColorQuest XE model, Reston, USA). Additionally, the values of chroma $\left(C^{\star}\right)$ and hue angle $\left(h^{\star}\right)$ were calculated from $a^{\star}$ and $b^{*}$ values. The total color difference between the different formulations 
and over storage was calculated according to the Equation 1, where $\Delta$ is the difference between each color parameter of the beverages. The container used in the analysis had a capacity of $50 \mathrm{~mL}$, with a thickness of $1 \mathrm{~cm}$.

$\Delta E=\sqrt{\left(\Delta L^{*}\right)^{2}+\left(\Delta a^{*}\right)^{2}+\left(\Delta b^{*}\right)^{2}}$

\subsection{Determination of total anthocyanins, total phenols and antioxidant capacity of the beverages}

Five grams of each formulation was weighted, and then $10 \mathrm{~mL}$ of ethanol: HCL solution $1.5 \mathrm{~mol} \cdot \mathrm{L}^{-1}(85: 15) \mathrm{v} / \mathrm{v}$ was added and the mixture was centrifuged at $2500 \mathrm{~g}$ for 5 minutes. The supernatant was removed and $5 \mathrm{~mL}$ of the ethanol: HCL solution $1.5 \mathrm{~mol} \cdot \mathrm{L}^{-1}(85: 15) \mathrm{v} / \mathrm{v}$ was added to the precipitate and the same procedure described previously was performed. The supernatants were combined and the volume was completed to $25 \mathrm{~mL}$. The spectrophotometer (Shimadzu- UV-VIS $1601 \mathrm{Pc}$ ) was used in all analyses.

Total anthocyanins content was determined according to the method described by Lees \& Francis (1972) and the results were expressed as $\mathrm{mg}$ of total anthocyanins $100 \mathrm{~g}^{-1}$ of beverage. Total phenols content was determined according to Singleton \& Rossi (1965), using the Folin-Ciocalteu reagent and gallic acid as standard. The results were expressed as $\mathrm{mg}$ GAE$\cdot 100 \mathrm{~g}^{-1}$ of beverage.

The TEAC assay (Trolox equivalent antioxidant capacity) using the ABTS radical (2,2'-azinobis-3-ethyl-benzothiazoline-6-sulfonate) was used to determine the antioxidant capacity according to the methodology described by Re et al. (1999). The results were expressed as $\mu \mathrm{mol}$ TEAC $\cdot \mathrm{g}^{-1}$ of beverage.

\subsection{Sensory analysis}

The study with consumers was approved by the Ethics Committee for Research with Human Beings of the Universidade Federal de Viçosa (registration: 26823514.4.0000.5153), Viçosa, MG, Brazil. The acceptance test was conducted in a laboratory with individual cabins. It was performed with 112 consumers who evaluated the whey protein beverages containing anthocyanins from jabuticaba skins (F1, F2, F3 and F4) for the attributes of color and overall impression. Beverage formulations were kept in closed bottles in a refrigerator $\left(5 \pm 2{ }^{\circ} \mathrm{C}\right)$ until testing and were removed from refrigerator $60 \mathrm{~min}$ prior to the sensory acceptance test, which allowed the samples to equilibrate to room temperature $\left(21 \pm 2^{\circ} \mathrm{C}\right)$. The samples were presented in monadic form, $50 \mathrm{~mL}$ plastic cups, coded with three digit numbers. The evaluations were performed using the 9-point hedonic scale according to Minim (2010), ranging from "extremely liked" (9) to "extremely disliked" (1).

\subsection{Stability study}

The stability of the beverage formulation with the best sensory acceptance was evaluated over the storage time $\left(0,7,15,30,45\right.$ and 60 days) under refrigeration $\left(5 \pm 2{ }^{\circ} \mathrm{C}\right)$. The performed analyses were: antioxidant capacity, total anthocyanins, color, $\mathrm{pH}$, total soluble solids and acidity, as described in the items 2.7 to 2.9 .

\subsection{Statistical analyses}

The effects of protein content and time on the physicochemical properties of the beverages were evaluated by simple regression analysis, at the level of $5 \%$ of significance. The results of the sensory acceptance were evaluated by the Principal Component Analysis through the Internal Preference Map (Minim, 2010). The statistical software used was the SAS (Statistical Analysis System), 9.1 version, 2008, licensed to the Federal University of Vicosa.

\section{Results and discussion}

\subsection{Anthocyanins from jabuticaba skins}

The anthocyanins delphinidin-3-glucoside and cyanidin-3-glucoside were identified in the phenolic extract obtained from jabuticaba skins. Their identification was based on comparison of the spectroscopic data, in particular the mass spectra, with data obtained from authentic standards and from the literature (Rebello et al., 2013). Cyanidin and delphinidin were identified based on the fragmentation of anthocyanin molecules which yielded products with $\mathrm{m} / \mathrm{z}$ values of 303 and 287. The identification of monoglucoside structures was based on the fragmentation patterns observed in the $\mathrm{Ms} / \mathrm{Ms}$ spectra, which occurred the appearance of only one type of fragment, characterizing the loss of one glucose $(\mathrm{m} / \mathrm{z}=162)$. The cyanidin-3-glucoside was the predominant, $198.0 \mathrm{mg} \cdot \mathrm{L}^{-1}$ extract. The concentration of delphinidin-3-glucoside was about twenty times lower, $9.8 \mathrm{mg} \cdot \mathrm{L}^{-1}$ extract. These results are in accordance with the data reported by Reynertson et al. (2008); Wu et al. (2012); Inada et al. (2015), where cyanidin-3-glucoside was the most abundant anthocyanin found in jabuticaba.

\subsection{Chemical composition of the beverage formulations}

The protein contents presented in the Table 1 indicated that the protein proportions were maintained (approximate values: $\mathrm{F} 1=0.5 \%, \mathrm{~F} 2=2.0 \%, \mathrm{~F} 3=4.0 \%$ and $\mathrm{F} 4=6.0 \%$ ) in each beverage formulation. There was no significant effect $(p>0.05)$ of the protein content on the $\mathrm{pH}$ values of the formulations, since that the $\mathrm{pH}$ was kept at 4.0. There was a positive influence of the protein content on the total soluble solids and acidity values of the formulations $(p<0.05)$. Studies have shown that proteins and amino acids contribute to increase the acidity in foods. Fox \& McSweeney (1998) reported that the substances responsible for the natural acidity of milk are minerals (phosphates and citrates), proteins (casein and albumin) and dissolved carbon dioxide. Lehninger et al. (2004) described that whey proteins are rich in the amino acids lysine, histidine and arginine, which are amino acids that have a positive charged side chain group contributing to decrease the acidity.

The presence of amino acids with specific structures as well as the addition of citric acid to the formulations contributed to the variation in acidity. Beverages formulated with higher protein concentration required a larger quantity of citric acid to reach the desired $\mathrm{pH}$ (4.0). Whey proteins have the structure that 
Table 1 . Physicochemical properties of the whey protein beverages with added anthocyanins from jabuticaba skins.

\begin{tabular}{cccccc}
\hline Formulations & $\mathrm{pH}$ & $\mathrm{TSS}\left({ }^{\circ} \mathrm{Brix}\right)^{*}$ & $\begin{array}{c}\text { Acidity } \\
\left(\mathrm{g} \text { of citric acid } \cdot 100^{-1} \mathrm{~g}\right)\end{array}$ & $\begin{array}{c}\text { Protein }\left(\mathrm{g} \cdot 100^{-1} \mathrm{~g}\right) \\
\text { Viscosity }(\mathrm{mPa} . \mathrm{s}) \\
10^{\circ} \mathrm{C}\end{array}$ \\
\hline F1 & $3.9 \pm 0.2$ & $21.1 \pm 0.1$ & $0.5 \pm 0.1$ & $0.60 \pm 0.02$ & $<20.0$ \\
F2 & $4.0 \pm 0.1$ & $22.6 \pm 0.4$ & $0.7 \pm 0.1$ & $2.30 \pm 0.03$ & $<20.0$ \\
F3 & $4.1 \pm 0.1$ & $24.0 \pm 0.3$ & $0.8 \pm 0.1$ & $4.0 \pm 0.06$ & 21.0 \\
F4 & $4.1 \pm 0.1$ & $27.0 \pm 1.2$ & $1.0 \pm 0.2$ & $6.0 \pm 0.01$ & 62.0 \\
\hline
\end{tabular}

$\mathrm{F} 1=$ formulation with $0.5 \%$ protein; F2 = formulation with $2.0 \%$ protein; F3 = formulation with $4.0 \%$ protein; F4 = formulation with $6.0 \%$ protein; ${ }^{\star}$ TSS $=$ total soluble solids. The values represent the average of 3 repetitions \pm standard deviation.

contributes to their good stability in solution, acting in a very wide $\mathrm{pH}$ range (Taulier \& Chalikian, 2001; Hosseinpour et al., 2011). This phenomenon is called buffer effect of whey proteins, where even with the addition of acids, the $\mathrm{pH}$ remains constant.

The beverages $\mathrm{F} 1$ and $\mathrm{F} 2$, formulated with whey permeate (WP) and whey retentate (WR), had their viscosities lower than $20 \mathrm{mPa}$.s (Table 1). These viscosity values are small and can be compared with the viscosity of unfermented dairy beverages. Yanes et al. (2002) observed the rheological behavior of chocolate dairy beverages and verified that the viscosity varied from 2.7 to $18.7 \mathrm{mPa}$.s at the temperature of $25^{\circ} \mathrm{C}$, and an increase in viscosity was observed at the temperature of $5^{\circ} \mathrm{C}$. The beverages F3 and F4 had viscosities of 21.0 and $62.0 \mathrm{mPa}$.s, respectively. Thus, higher protein content resulted in higher viscosity in the beverages. These results can directly influence the sensorial acceptance of this product.

\subsection{Color analysis}

The color analysis showed important differences between the formulations (Figure 1A). The protein content considerably influenced $(p<0.05)$ the $L^{*}$ values of the beverages. The higher the protein content, clearer became the beverages. This difference can be attributed to the different whey protein sources (WP, WR or WPC 60) used in the formulations. The WP was subjected only to the microfiltration process, keeping the original color of the cheese whey. The WR obtained from the ultrafiltration presented a clearer color, while the commercial whey protein (WPC 60) when solubilized was even clearer than the WR.

The effect of the protein content on the values of $\mathrm{a}^{*}$ and $\mathrm{C}^{\star}$ of the beverages was not significant $(\mathrm{p}>0.05)$ (Figure 1A). The $\mathrm{a}^{*}$ parameter provided positive values while the $\mathrm{C}^{*}$ values ranged from 10.5 to 13.7 as the protein content increased. In the color diagram, the $\mathrm{h}^{\star}$ parameter represents the hue angle, and their values varied between 13.4 and 37.8 degrees. Therefore, the beverages presented hues ranging from red to yellow, tending to a red color. Sari et al. (2012) verified the values of the $\mathrm{L}^{\star}, \mathrm{C}^{\star}$ and $\mathrm{h}^{\star}$ color coordinates in beverages formulated with citrate buffer, $\mathrm{pH} 3.0$, with added anthocyanins extracted from jambolan (Syzygium cumini). The $\mathrm{L}^{*}, \mathrm{C}^{*}$ and $\mathrm{h}^{*}$ obtained values were $62.5,24.9$ and 0.6 , respectively. The $\mathrm{L}^{*}$ value was very close to the $\mathrm{F} 4$ formulation, however, the $\mathrm{C}^{*}$ coordinate was higher than the value found in the present work, indicating a higher intensity of the red color for the beverages prepared with jambolan anthocyanins. This fact can be explained by the differences in formulations and the $\mathrm{pH}$ of the beverages.

The color differences between formulations can also be evaluated by the total color difference $(\Delta \mathrm{E})$, which allows to determine how
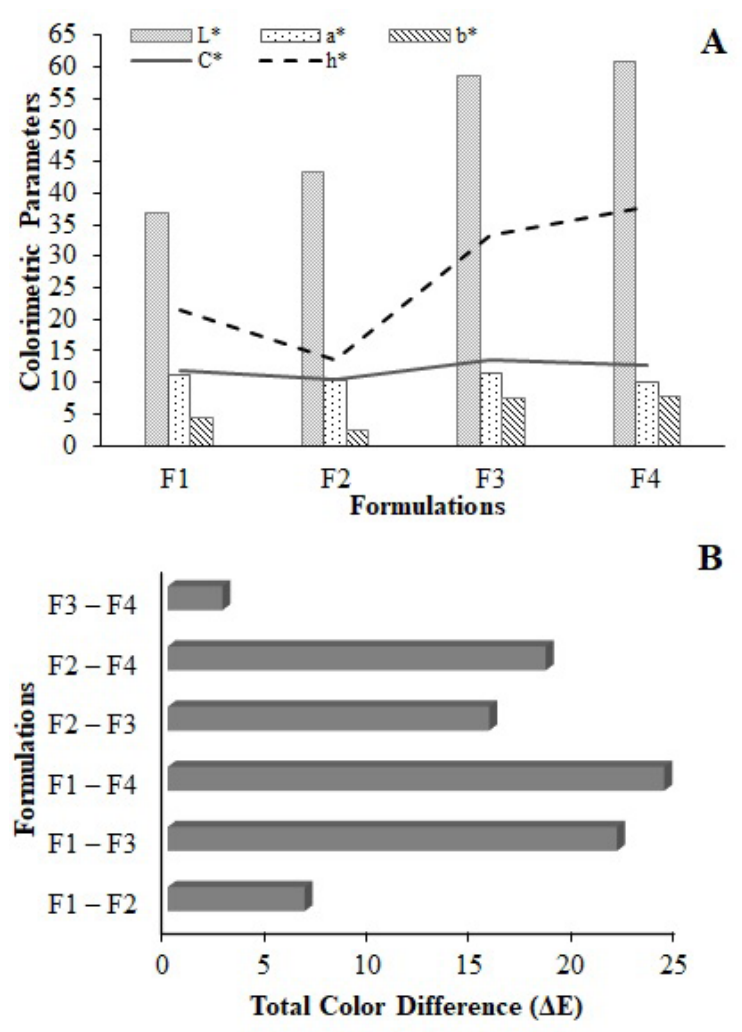

Figure 1. Colorimetric analysis of the whey protein beverages. $\mathrm{L}^{*}=$ luminosity; $\mathrm{a}^{*}=$ red vs green; $\mathrm{b}^{*}=$ yellow vs blue; $\mathrm{h}^{\star}=$ hue angle (degrees); $\mathrm{C}^{\star}=$ color saturation: $(\mathrm{A}) . \Delta \mathrm{E}=$ total color difference; $\mathrm{F} 1=$ formulation with $0.5 \%$ protein; $\mathrm{F} 2=$ formulation with $2.0 \%$ protein; $\mathrm{F} 3=$ formulation with $4.0 \%$ protein; and $\mathrm{F} 4=$ formulation with $6.0 \%$ protein: (B).

much the overall impression is different between samples and whether there exists perceptible sensory differences between them. It was observed that only one pair of formulations (F3/F4) had $\Delta \mathrm{E}$ value lower than five (Figure 1B). Obón et al. (2009) proposed that the total color differences $(\Delta \mathrm{E})$ between samples higher than 5 (the visual discrimination threshold) are distinguished by an observer. However there are criteria even stricter, where $\Delta \mathrm{E}$ values higher than 3 indicate that the differences between samples are much easier to distinguish (Adekunte et al., 2010; Pathare et al., 2013). It was verified that the protein content influenced the total color difference between formulations and that greater differences were observed between pairs of formulations containing low and 
high protein contents, which may directly influence the sensorial acceptance of these products.

\subsection{Total anthocyanins, total phenols and antioxidant capacity}

The contents of total anthocyanins, total phenols and antioxidant capacity of the beverages are presented in Table 2 . Total anthocyanins content did not vary significantly $(p>0.05)$ with the increase of the protein content, while for total phenols and antioxidant capacity, there was a significant variation $(\mathrm{p}<0.05)$ with the increase of the protein content of the formulations. Total anthocyanins ranged from 1.4 to $1.8 \mathrm{mg} \cdot 100 \mathrm{~g}^{-1}$ of beverage. These results indicated the importance to standardize the anthocyanin content of the formulations. These whey protein beverages containing anthocyanins from jabuticaba skins, especially the cyanidin-3-glucoside and delphinidin-3-glucoside, may be claimed as a functional food due to the high antioxidant capacity of the anthocyanins and their biological properties, which are extensively studied (Galvano et al., 2004).

The variation of the antioxidant capacity between the beverages was very low (from 1.2 to $1.8 \mu \mathrm{mol} \mathrm{TEAC} \cdot \mathrm{g}^{-1}$ ) (Table 2), the beverages presented a good antioxidant capacity when compared to Rocha et al. (2017), which evaluated the antioxidant capacity of added protein drinks of lutein, values were between 0.09 to $0.11 \mu \mathrm{mol}$ TEAC $\cdot \mathrm{g}^{-1}$, much lower than that presented by the present study. The content of total phenols of the beverages was positively influenced $(\mathrm{p}<0.05)$ by the protein content. The concentration of total phenols in the phenolic extract from jabuticaba skins was $13.5 \mathrm{mg}$ AGE. $\mathrm{mL}^{-1}$ of extract. A volume of $2.0 \mathrm{~mL}$ of the extract was added in each formulation with the objective to reach about $27.0 \mathrm{mg}$ of total phenols $100 \mathrm{~g} \mathrm{~g}^{-1}$ of beverage. However, all formulations had their concentration of total phenols higher than the estimated (Table 2). This fact may have happened due to the presence of interferents that reacted with the Folin-Ciocalteu reagent (FC) in the formulations.

One of the limitations of this method is the capacity that the FC has to react with all the reducing substances present, leading to an overestimation of the results (Naczk \& Shahidi, 2004). Most sources of phenolic compounds also have other reducing substances such as ascorbic acid, citric acid, amino acids and sugars, which are accounted for as total phenols in the final result (Rover \& Brown, 2013). The interference in the total phenol values in this study was probably due to the presence of aminoacids, from the whey proteins, and citric acid, used as acidulant in the beverages. Singleton et al. (1999) observed that citric acid at a concentration of $1 \mathrm{mg} \cdot \mathrm{mL}^{-1}$ increased by $25 \%$ the absorbance of the samples in the analysis of total phenols using the $\mathrm{FC}$ at $20^{\circ} \mathrm{C}$, while glucose did not interfere in the results, because it does not substantially react with $\mathrm{FC}$ at room temperature.

\subsection{Sensory analysis}

On the internal preference map, generated from overall impression and color data of the whey protein beverages (Figure 2A), the first principal component explained 56.27\% and the second, $22.49 \%$. Together they explained $78.76 \%$ of the total variability of the acceptance data. In addition, for the color attribute, the first principal component explained 59.77\%, the second, $30.49 \%$ and together they explained $90.26 \%$ of the
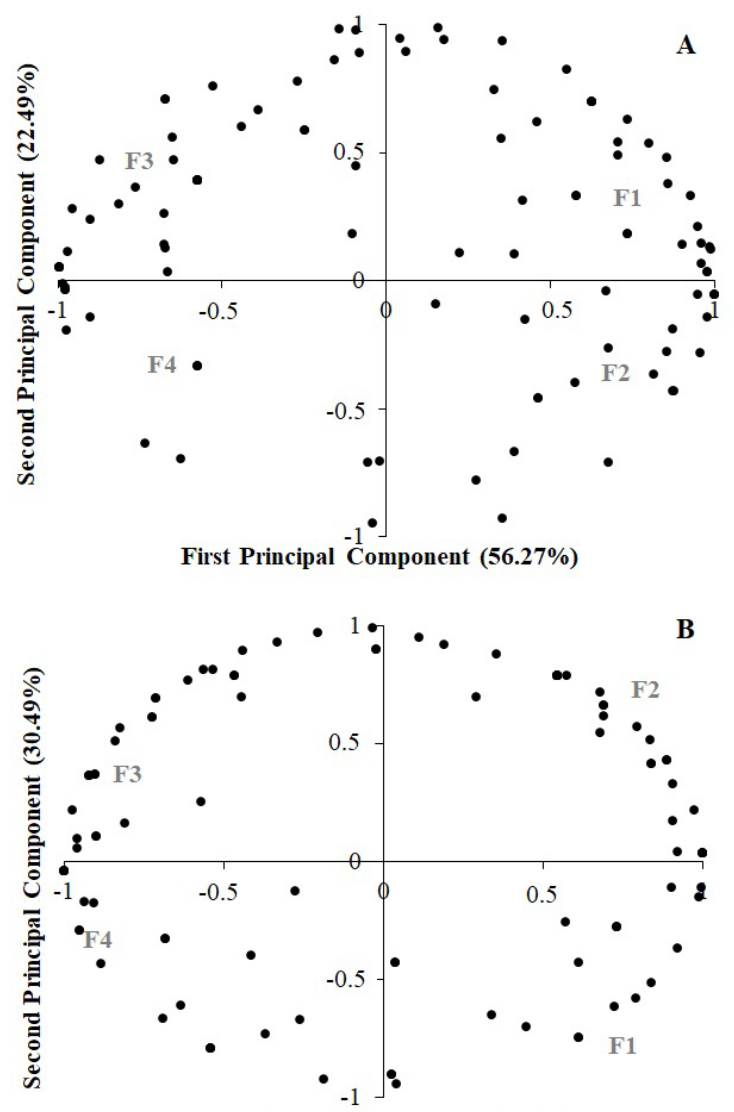

First Principal Component (59.77\%)

Figure 2. Graphical representation of the whey protein beverages with added anthocyanins from jabuticaba skins and consumers in relation to the two principal components, as for the overall impression (A) and color (B).

Table 2. Total anthocyanins, total phenols and antioxidant capacity of the whey protein beverages with added anthocyanins from jabuticaba skins.

\begin{tabular}{cccc}
\hline Formulations & Total anthocyanins $\left(\mathrm{mg} \cdot 100 \mathrm{~g}^{-1}\right)$ & Total phenols $\left(\mathrm{mg} \mathrm{GAE} \cdot 100 \mathrm{~g}^{-1}\right)$ & $\begin{array}{c}\text { Antioxidant capacity } \\
\left(\mu \mathrm{mol} \mathrm{TEAC} \cdot \mathrm{g}^{-1}\right)\end{array}$ \\
\hline F1 & $1.5 \pm 0.3$ & $32.6 \pm 1.0$ & $1.2 \pm 0.2$ \\
F2 & $1.6 \pm 0.7$ & $55.3 \pm 3.2$ & $1.4 \pm 0.2$ \\
F3 & $1.8 \pm 0.4$ & $74.0 \pm 2.5$ & $1.8 \pm 0.2$ \\
F4 & $1.4 \pm 0.1$ & $83.6 \pm 6.2$ & $1.5 \pm 0.1$ \\
\hline
\end{tabular}

$\mathrm{F} 1$ = formulation with $0.5 \%$ protein; F2 = formulation with $2.0 \%$ protein; F3 = formulation with $4.0 \%$ protein; F4 = formulation with $6.0 \%$ protein; GAE = Gallic acid equivalent;

TEAC $=$ Trolox equivalent antioxidant capacity. The values represent the average of 3 repetitions \pm standard deviation. 
Table 3. Variation of the colorimetric parameters during 60 days storage of the beverage formulation F3.

\begin{tabular}{ccccc}
\hline $\begin{array}{c}\text { Time } \\
(\text { days })\end{array}$ & $\begin{array}{c}\text { Luminosity } \\
\left(\mathrm{L}^{*}\right)\end{array}$ & $\begin{array}{c}\text { Chroma } \\
\left(\mathrm{C}^{*}\right)\end{array}$ & $\begin{array}{c}\text { Hue } \\
\left(\mathrm{h}^{*}\right)\end{array}$ & Total Color Difference $(\Delta \mathrm{E})$ \\
\hline 0 & $58.6 \pm 2.0$ & $13.7 \pm 0.8$ & $33.4 \pm 3.1$ & $1.8 \pm 0.5$ \\
7 & $58.6 \pm 3.0$ & $13.5 \pm 0.5$ & $39.5 \pm 7.4$ & $2.1 \pm 0.3$ \\
15 & $59.4 \pm 2.7$ & $13.0 \pm 0.6$ & $41.3 \pm 6.3$ & $2.6 \pm 1.0$ \\
30 & $59.0 \pm 2.9$ & $13.2 \pm 1.0$ & $43.8 \pm 8.7$ & $2.8 \pm 0.5$ \\
45 & $59.1 \pm 3.0$ & $12.9 \pm 1.1$ & $45.0 \pm 7.2$ & $3.0 \pm 1.0$ \\
60 & $59.0 \pm 3.1$ & $12.9 \pm 1.2$ & $45.8 \pm 9.2$ & \\
\hline
\end{tabular}

F3 = beverage containing $4.0 \%$ protein with added anthocyanins from jabuticaba skins. The values represent the average of 3 repetitions \pm standard deviation.

total variability of the acceptance data related to the beverage color (Figure $2 \mathrm{~B}$ ). Both data of the principal components are considered sufficient to discriminate the samples on the overall impression and color.

Consumers are represented by points in each abscissa and ordinate. The correlation of consumers with at least one of the components indicates a difference in the acceptance of the formulations. On the preference map, the consumers are located next to the products they liked the best (Silva et al., 2012). The spatial separation of samples (Figure 2A) indicated the formation of four groups to discriminate the overall impression of the samples. The first, second, third and fourth groups were composed by the F1, F3, F4 and F2 formulations, respectively.

A small group of consumers negatively correlated with the first and second principal components, tending to accept more the F4 beverage, which was darker and had the highest viscosity value among the formulations (Table 1 and Figure 1A). There was a homogeneous distribution of consumers in relation to the principal components for the F1, F2 and F3 beverages, indicating that they were equally accepted, and therefore, they were the formulations that had the greatest acceptance to the overall impression. These beverage formulations had lighter colors and lower viscosities compared to F4 (Table 1 and Figure 1A). Moreover, it is interesting to observe that the formulations F1, F2 and F3 had whey proteins from different sources (F1 and F2: whey permeate and whey retentate, respectively); F3: commercial whey protein concentrate) and were still well accepted by the consumers, which open opportunities for the food industries to use the whey proteins obtained from different processes.

The spatial separation of the samples for the color attribute (Figure 2B) indicated a similar behavior compared to the overall impression. There was also the formation of four distinct groups for discriminating the color of the formulations. There was no tendency presented by the consumers. None of the samples was directly influenced by an opinion of a distinct group, indicating that the color attribute of the beverages was similarly evaluated between formulations.

In contrast, the instrumental color analysis showed variations among the values of some colorimetric parameters due to the different protein contents used in each formulation. However, the $\mathrm{a}^{\star}$ parameter (intensity of the red and green color) showed no significant difference $(\mathrm{p}>0.05)$ between formulations. This same behavior was also observed for the $\mathrm{C}^{\star}$ values, indicating that the data of sensory acceptance to the color attribute had a good correlation with the instrumental color analysis for the $\mathrm{a}^{\star}$ and $\mathrm{C}^{\star}$ parameters.

\subsection{Stability study}

The whey protein beverage F3 was evaluated during the stability study due to its higher protein content and antioxidant capacity (Tables 1 and 2, respectively) among the formulations that had better sensory acceptance (F1, F2 and F3). Throughout the 60 days of storage, the beverage acidity, soluble solids and $\mathrm{pH}$ did not vary significantly ( $\mathrm{p}>0.05)$, ranging from 0.77 to $0.81 \mathrm{~g}$ of citric acid $100 \mathrm{~g}^{-1}, 24.1$ to $23.6^{\circ}$ Brix and 4.03 to 4.08 , respectively. The $\mathrm{pH}$ standardization, the storage under refrigeration and the addition of potassium sorbate were important to stop the growth of microorganisms and consequently to keep the beverage stable against $\mathrm{pH}$ and acidity changes.

The total anthocyanin content ranged from 1.8 to $1.7 \mathrm{mg} \cdot 100 \mathrm{~g}^{-1}$ of beverage, throughout the 60 days of storage, confirming that the storage conditions tested did not promote the degradation of this phenolic compound. The antioxidant capacity also followed the same behavior of the anthocyanins. There was no significant variation $(p>0.05)$ during the storage period and the values varied from 1.8 to $1.6 \mu \mathrm{mol}$ TEAC $\cdot \mathrm{g}^{-1}$. The maintenance of the antioxidant capacity may be explained by the fact that the content of total anthocyanins (most important antioxidant in the jabuticaba phenolic extract) did not change, emphasizing the important relation between the antioxidant capacity and the levels of bioactive compounds in foods.

There were no significant differences $(p>0.05)$ in the beverage colorimetric parameters over the storage period (Table 3 ).

Nevertheless, there was a variation $(\mathrm{p}<0.05)$ in the total color difference $\Delta \mathrm{E}$, which increased during the storage time. Despite the significant differences in $\Delta \mathrm{E}$ values of $\mathrm{F} 3$ over storage time, they were lower than 3 . This difference is considered insignificant, and it is not perceptible to the human eye. Thus, it does not have any influence in the sensory acceptance of the beverage.

\section{Conclusions}

The cianidin-3-O-glucoside and delphinidin-3-O-glucoside were the two major anthocyanins found in the phenolic extract from jabuticaba skins. The anthocyanins contributed to a high antioxidant capacity observed in the whey protein beverages and can be used as potential natural colorant in foods. The F3 beverage 
maintained its physical and chemical properties, including their content of total anthocyanins and antioxidant capacity during storage under refrigeration. There was a good sensory acceptance of the whey protein beverage containing $4 \%$ of proteins and anthocyanins from jabuticaba skins. Thus, this whey protein beverage containing anthocyanins is a promising product to the market due to its high protein quality and bioactive properties.

\section{Acknowledgements}

To the company Gemacom Tech, for providing the commercial whey protein concentrate. To the company Duas Rodas Industrial for providing the flavors. To the Research Support Foundation of the State of Minas Gerais-Brazil (FAPEMIG), for the scholarship, and to the Brazilian National Council for Scientific and Technological Development (CNPq), for the financial support.

\section{References}

Adekunte, A. O., Tiwari, B. K., Cullen, P. J., Scannell, A. G. M., \& O'Donnell, C. P. (2010). Effect of sonication on colour, ascorbic acid and yeast inactivation in tomato juice. Food Chemistry, 122(3), 500-507. http://dx.doi.org/10.1016/j.foodchem.2010.01.026.

Association of Official Analytical Chemists - AOAC. (2005). Official methods of analysis of AOAC International (18th ed.). Maryland: AOAC International.

Fox, P. F., \& McSweeney, P. L. H. (1998). Dairy chemistry and biochemistry. New York: Blackie Academic \& Professional/Tomphson Science.

Galvano, F., La Fauci, L., Lazzarino, G., Fogliano, V., Ritieni, A., Ciappellano, S., Battistini, N. C., Tavazzi, B., \& Galvano, G. (2004). Cyanidins: metabolism and biological properties. The Journal of Nutritional Biochemistry, 15(1), 2-11. http://dx.doi.org/10.1016/j. jnutbio.2003.07.004. PMid:14711454.

Hosseinpour, S., Izadi, M., Aminlari, M., Ramezani, R., \& Tavana, M. (2011). Changes in the solubility and SDS-PAGE profile of whey proteins during storage at different temperatures: a kinetic study. Journal of Food and Agriculture Science, 1, 15-21.

Inada, K. O. P., Oliveira, A. A., Revorêdo, T. B., Martins, A. B. N., Lacerda, E. C. Q., Freire, A. S., Braz, B. F., Santelli, R. E., Torres, A. G., Perrone, D., \& Monteiro, M. C. (2015). Screening of the chemical composition and occurring antioxidants in jabuticaba (Myrciaria jaboticaba) and jussara (Euterpe edulis) fruits and their fractions. Journal of Functional Foods, 17, 422-433. http://dx.doi. org/10.1016/j.jff.2015.06.002.

Instituto Adolfo Lutz - IAL. (2008). Métodos físico-químicos para análise de alimentos. São Paulo: IAL.

Katsanos, C. S., Kobayashi, H., Sheffield-moore, M., Aarsland, A., \& Wolfe, R. R. (2006). A high proportion of leucine is required for optimal stimulation of the rate of muscle protein synthesis by essential amino acids in the elderly. American Journal of Physiology, Endocrinology and Metabolism, 291(2), 381-387. http://dx.doi. org/10.1152/ajpendo.00488.2005. PMid:16507602.

Lees, D. H., \& Francis, F. J. (1972). Standardization of pigment analysis in Cranberries. Hortiscience, 7(1), 83-84.

Lehninger, A. L., Nelson, D. L., \& Cox, M. M. (2004). Lehninger principles of Biochemistry (4th ed.). New York: W.H. The Freeman.

Minim, V. P. R. (2010). Análise sensorial: estudos com consumidores. Viçosa: Editora UFV.
Naczk, M., \& Shahidi, F. (2004). Extraction ad analysis of phenolics in foods. Journal of Chromatography A, 1054(1-2), 95-111. http:// dx.doi.org/10.1016/S0021-9673(04)01409-8. PMid:15553136.

Neves, B. (1993). Elaboração de bebidas lácteas a base de soro. Leite \& Derivados, (10), 50-54.

Obón, J. M., Castellar, M. R., Alacid, M., \& Fernández-lópez, J. A. (2009). Production of a red-purple food colorant from Opuntia stricta fruits by spray drying and its application in food model systems. Journal of Food Engineering, 90(4), 471-479. http://dx.doi.org/10.1016/j. jfoodeng.2008.07.013.

Pathare, P. B., Opara, U. L., \& Al-said, F. A.-J. (2013). Colour measurement and analysis in fresh and processed foods: a review. Food and Bioprocess Technology, 6(1), 36-60. http://dx.doi.org/10.1007/ s11947-012-0867-9.

Pescuma, M., Hébert, E. M., Mozzi, F., \& Valdez, G. F. (2010). Functional fermented whey-based beverage using lactic acid bacteria. International Journal of Food Microbiology, 141(1-2), 73-81. http:// dx.doi.org/10.1016/j.ijfoodmicro.2010.04.011. PMid:20483186.

Quideau, S., Deffieux, D., Douat-Casassus, C., \& Pouységu, L. (2011). Plant polyphenols: chemical properties, biological activities, and synthesis. Angewandte Chemie International Edition, 50(3), 586621. http://dx.doi.org/10.1002/anie.201000044. PMid:21226137.

Re, R., Pellegrini, N., Proteggente, A., Pannala, A., Yang, M., \& Rice-evans, C. (1999). Antioxidant activity applying an improved ABTS radical cation decolorization assay. Free Radical Biology \& Medicine, 26(910), 1231-1237. http://dx.doi.org/10.1016/S0891-5849(98)00315-3. PMid:10381194.

Rebello, L. P. G., Lago-Vanzela, E. S., Barcia, M. T., Ramos, A. M., Stringheta, P. C., Silva, R., Castillo-Muñoz, N., Gómez-Alonso, S., \& Hermosín-Gutiérrez, I. (2013). Phenolic composition of the berry parts of hybrid grape cultivar BRS Violeta (BRS Rubea× IAC 139821) using HPLC-DAD-ESI-MS/MS. Food Research International, 54(1), 354-366. http://dx.doi.org/10.1016/j.foodres.2013.07.024.

Reynertson, K. A., Yang, H., Jiang, B., Basile, M. J., \& Kennelly, E. J. (2008). Quantitative analysis of antiradical phenolic constituents from fourteen edible Myrtaceae fruits. Food Chemistry, 109(4), 883-890. http://dx.doi.org/10.1016/j.foodchem.2008.01.021. PMid:21340048.

Rocha, J. D. C. G., Mendonça, A. C., Viana, K. W. C., Maia, M. D. P., Carvalho, A. F. D., Minim, V. P. R., \& Stringheta, P. C. (2017). Beverages formulated with whey protein and added lutein. Ciência Rural, 47(3), e20151606. http://dx.doi.org/10.1590/0103-8478cr20151606.

Rodrigues, S., Fernandes, F. A. N., Brito, E. S., Sousa, A. D., \& Narain, N. (2015). Ultrasound extraction of phenolics and anthocyanins from jabuticaba peel. Industrial Crops and Products, 69, 400-407. http://dx.doi.org/10.1016/j.indcrop.2015.02.059.

Rover, M. R., \& Brown, R. C. (2013). Quantification of total phenols in bio-oil using the FolinCiocalteu method. Journal of Analytical and Applied Pyrolysis, 104, 366-371. http://dx.doi.org/10.1016/j. jaap.2013.06.011.

Sabaa-srur, A. U. O., Koblitz, M. G. B., Freimaw, L. O., Oliveira, V., \& Gonçalves, E. B. (1995). Uso integral do soro de queijo Minas frescal na elaboração de bebida láctea fermentada e sua aceitabilidade. Revista de Ciências Exatas, 17(1/2), 57-62.

Sari, P., Wijaya, C. H., Sajuthi, D., \& Supratman, U. (2012). Colour properties, stability, and free radical scavenging activity of jambolan (Syzygium cumini) fruit anthocyanins in a beverage model system: natural and copigmented anthocyanins. Food Chemistry, 132(4), 1908-1914. http://dx.doi.org/10.1016/j.foodchem.2011.12.025.

Silva, M. C., Souza, V. B. D., Thomazini, M., Silva, E. R., Smaniotto, T., Carvalho, R. A. D., Genovese, M. I., \& Favaro-Trindade, C. S. 
(2014). Use of the jabuticaba (Myrciaria cauliflora) depulping residue to produce a natural pigment powder with functional properties. Lebensmittel-Wissenschaft + Technologie, 55(1), 203-209. http:// dx.doi.org/10.1016/j.lwt.2013.08.026.

Silva, R. D. C. D. S. N., Minim, V. P. R., Lima, L. P., Gomide, A. I., Moraes, L. E. S., \& Minim, L. A. (2012). Otimização da aceitabilidade sensorial de requeijão cremoso light. Ciência Rural, 42(2), 360-366. http://dx.doi.org/10.1590/S0103-84782012000200027.

Singleton, V. L., \& Rossi, J. A. Jr. (1965). Colorimetry of total phenolics with phosphomolybdic-phosphotungstic acid reagents. American Journal of Enology and Viticulture, 16, 144-158.

Singleton, V. L., Orthofer, R., \& Lamuela-raventos, R. M. (1999). Analysis of total phenols and other oxidation substrates and antioxidants by means of Folin-Ciocalteu reagent. Methods in Enzymology, 299, 152-178. http://dx.doi.org/10.1016/S0076-6879(99)99017-1.
Siso, M. G. (1996). The biotechnological utilization of cheese whey: a review. Bioresource Technology, 57(1), 1-11. http://dx.doi. org/10.1016/0960-8524(96)00036-3.

Taulier, N., \& Chalikian, T. (2001). Characterization of pH-induced transtitions of $\beta$-LG: ultrassonic, densitometric, and spectroscopy studies. Journal of Molecular Biology, 314(4), 873-889. http://dx.doi. org/10.1006/jmbi.2001.5188. PMid:11734004.

Wu, S., Dastmalchi, K., Long, C., \& Kennelly, E. J. (2012). Metabolite profiling of jaboticaba (Myrciaria cauliflora) and other dark-colored fruit juices. Journal of Agricultural and Food Chemistry, 60(30), 7513-7525. http://dx.doi.org/10.1021/jf301888y. PMid:22809264.

Yanes, M., Duran, L., \& Costell, E. (2002). Rheological and optical properties of commercial chocolate milk beverages. Journal of Food Engineering, 51(3), 229-234. http://dx.doi.org/10.1016/S02608774(01)00061-9. 